\title{
STRATEGI PENGELOLAAN LINGKUNGAN DI DANAU BUYAN KABUPATEN BULELENG
}

\author{
Ely Santari $^{\left.1^{*}\right)}$, Syamsul Alam Paturusi ${ }^{2)}$, A.A.P. Agung Suryawan ${ }^{3)}$ \\ ${ }^{1)}$ Balai Konservasi Sumber Daya Alam, Bali \\ ${ }^{2)}$ Magister Ilmu Lingkungan Pascasarjana Universitas Udayana \\ ${ }^{3)}$ Pusat Unggulan Iptek Pariwisata Universitas Udayana \\ *Email: elysantari.bksda.kh@gmail.com
}

\section{ABSTRACT \\ ENVIRONMENTAL MANAGEMENT STRATEGY IN TWA LAKE BUYAN-TAMBLINGAN BULELENG}

\begin{abstract}
This research aimed to determine the potential of ecotourism that can be developed and to analyze visitor perceptions and to formulate environmental management strategies for development of ecotourism in TWA Danau Buyan. The method used in this research was descriptive qualitative with the techniques, namely observation, interviews and questionnaires. The result of this indicate that the potential tourist attractions in TWA Lake Buyan area already exist including jungle tracking, camping, cannoing, selfie spot, outbond locations that have paid attention to environmental issues by involving the community. The perceptions of visitors were based on the function of the area, management policies, tourism activities, facilities and infrastructure, and on the willingness to stay generally quite good. Based on the IE table, the management strategy matrix was in quadrant V (Five) or in the hold and maintain and survival phase. These strategies included: a) Developing the unique potential in TWA Lake Buyan both natural resource potentials such as biodiversity (flora and fauna), landscape beauty, and community socio-cultural potential that could be developed and packaged into ecotourism package, b) Increasing support from the local government and participation of local communities to optimize the quality improvement of ODTW TWA Danau Buyan, both facilities and infrastructure tourism, public facilities, human resources, and increasing the promotion of cultural and spiritual tourism to foreign tourist, c) Increasing supervision in field, increasing guidance and counseling on the benefits of tourist attraction to the community, as well as inviting the public and tourists to actively participated in preserving the forest and existing tourism objects (environmentally friendly tourism awareness activities), d) Build cooperation and synergy with competent stakeholders, including the Tourism Office, the KSDA unit, the Agriculture Office, Academics, Non-Governmental Organization, local community organizations, and open for opportunities to do collaboration with the surrounding community. Keywords: Strategy Management, Ecotourism, Nature Tourism Park, Buyan Lake
\end{abstract}

\section{PENDAHULUAN}

Pulau Bali merupakan destinasi wisata yang sudah lama berkembang dan cukup terkenal di dunia, baik karena keindahan alamnya, kuliner, kebudayaannya serta surga belanja bagi wisatawan dari dalam negeri maupun luar negeri. Menjadi hal umum apabila Pulau Bali penghasilan devisa negara terbesarnya berasal dari sektor pariwisata. Panorama alam yang menjadi daya tarik utama di Pulau Bali sangat baik untuk dioptimalkan. Kawasan Bedugul terkenal bagi wisatawan dalam negeri maupun luar negeri karena keindahan alamnya, seni budaya, dan hasil panenan budi daya tanaman agro, sehingga di samping masyarakat mendapatkan pendapatan dari sektor jasa juga mendapatkan hasil dari penjualan hasil panen sektor pertanian. Salah 
satu daerah tujuan wisata pada kawasan tersebut adalah TWA (Taman Wisata Alam) Danau Buyan Danau Tamblingan.

TWA Danau Buyan secara geografis terletak pada $8^{\circ} 14^{\prime} 9^{\prime \prime}-8^{\circ} 7^{\prime} 9^{\prime \prime}$ LS dan $115^{\circ} 5^{\prime} 18^{\prime \prime}$ - $115^{\circ} 11^{\prime} 20^{\prime \prime}$ BT, dan secara administratif kawasan TWA masuk di dua wilayah kabupaten, yaitu Kabupaten Tabanan dan Kabupaten Buleleng. TWA Danau Buyan berada di wilayah Resort KSDA BuyanTamblingan, Seksi Konservasi Wilayah I Balai KSDA Bali. Luas kawasan TWA Buyan adalah $1.703 \mathrm{Ha}$ sebagaimana disebutkan dalam surat Kepala kantor Wilayah Departemen Kehutanan Propinsi Bali Nomor 14/Kwl-5/1997 tanggal 22 Januari 1997 tentang Penetapan sebagian kawasan hutan Batukaru (RKT 4). Sedangkan penetapan kawasan TWA Danau Buyan terbaru adalah Keputusan Menteri Kehutanan Nomor.SK.2847/Menhut-VII/KUH/2014

Tanggal 16 April 2014 tentang Penetapan Kawasan Hutan Pada Kelompok Hutan Gunung Batukau (RTK.4) dengan luas kawasan yaitu 1.847,38 Ha (Balai KSDA Bali, 2000). Kawasan Danau Buyan termasuk ke dalam danau prioritas nasional II, yang pengelolaannya harus melibatkan seluruh stakeholder. Kawasan tersebut menjadi prioritas disebabkan kompleksnya permasalahan (Form Danau Indonesia, 2004). Pertama TWA Danau Buyan merupakan kawasan sosial budaya yang sangat penting bagi umat agama hindu, hal tersebut dicirikan adanya sekitar 40 pura dalam kawasan tersebut, tujuh diantaranya termasuk pura besar. Tujuh pura besar tersebut antara lain adalah Pura Pande, Pura Dalam Tambelingan, Pura Ulun Danu Buyan, Pura Guna Anyar, Pura Tajun, Pura Nyoman. Aktifitas pemeluk agama hindu di sekitar lokasi melaksanakan ibadah suci setiap hari-hari besar keagamaan seperti Galungan, Kuningan, Pagerwesi dan odalan (diadakan setiap 6 (enam) bulan sekali). Kedua secara ekologis TWA Danau Buyan adalah daerah tangkapan air hujan bagi kawasan di bawahnya termasuk desa-desa di Kabupaten Buleleng dan Tabanan. Berkembang pesatnya gulma air seperti enceng gondok, tercemarnya sumber air, pendangkalan, pengerukan, dan hilangnya plasma nutfah juga merupakan masalah ekologis di kawasan ini. Ketiga perubahan pola agrikultur petani pada kawasan tersebut. Petani sekitar TWA Danau Buyan lebih menyukai tanaman semusim seperti bungabungaan dan stroberi sebagai komoditas utama mereka. Hal tersebut menyebabkan tingkat erosi tinggi dan mempercepat pendangkalan danau. Keempat, potensi ekowisata di TWA Danau Buyan masih terbuka lebar. Selain fungsi ekologis dan sosial budaya, faktor keberlanjutan ekonomi masyarakat sekitar danau juga diperhatikan. Apabila pengusahaan wisata di daerah ini dilakukan sesuai dengan peraturan yang berlaku maka tujuan pembangunan kawasan berkelanjutan dapat tercapai.

Menurut Sutomo et al. (2014), daerah Danau Buyan dan Tamblingan adalah daerah tangkapan air hujan yang sangat penting bagi kehidupan masyarakat di Bali. Ekosistem Danau Buyan sebagai bagian dari kawasan konservasi memiliki fungsi sebagai sebagai pengatur tata air yang mencakup resapan, tangkapan, dan persediaan air bersih. Fungsi ini akan semakin hilang bilamana ekosistem Danau Buyan mengalami penurunan kualitasnya. Masyarakat sekitar danau menggunakan air danau untuk keperluan upacara, rumah tangga dan bertani. Termasuk kawasan catur desa (Desa Munduk, Gesing, Ombojero, Gobleg), Desa Pancasari, Desa Wanagiri (Kabupaten Buleleng), dan Desa Candikuning (Kabupaten Tabanan). Jadi apabila perubahan kualitas dan kuantitas air danau maka desa-desa tersebut akan terkena dampaknya. Sebagai contoh terjadinya banjir bandang pada tahun 2017 di areal pertanian sekitar kawasan tersebut yang membuat petani menderita kerugian yang cukup besar.Salah satu permasalahan sosial akibat pengurukan sempadan danau terjadi di Desa Pancasari. Pengurukan dilakukan masyarakat yang memiliki lahan pertanian agar tanaman budidaya tidak terendam banjir akibat air danau yang meluap. Namun akibat nya, penduduk desa lainnya yang berlokasi di bagian lereng atas danau menjadi tergenang, karena air hujan tidak dapat turun ke danau. Setelah dilakukan dialog dengan pemerintah kabupaten, maka dibangunlah saluran drainase bagi jalannya air permukaan (runoff) dari arah lereng menuju danau. Saluran drainase 
tersebut juga menjadi bentuk antisipasi pemerintah daerah apabila daerah tersebut terkena banjir bandang.

Nugroho Saptono et al. (2017), mengatakan hakekatnya pembangunan pariwisata dapat dimanfaatkan sebesarbesarnya bagi kesejahteraan masyarakat. Sudah sewajarnya apabila masyarakat lokal sebagai pemilik kebudayaan dan kearifan lokal mendapatkan manfaat dengan berkembangnya pariwisata di daerahnya. Selain manfaat secara ekonomi konsep pariwisata hijau juga menyediakan lapangan pekerjaan dan meningkatkan pola pikir masyarakat, sehingga dalam pengelolaannya masyarakat tetap dilibatkan mulai dari perencanaan, pelaksanaan, pengawasan, dan evaluasi. Sampai dengan saat ini atraksi wisata yang ditawarkan mencakup wisata minat khusus yaitu wisata tirta, memancing/ berperahu, berkemah, lintas alam/ penjelajahan (Budayasa, 2016). Berdasarkan pengamatan di lapangan kesempatan pengusahaan ekowisata di lokasi tersebut masih terbuka lebar.

TWA Danau Buyan Tamblingan adalah satu kawasan yang dikelola oleh Balai KSDA Bali yang ditujukan sebagai kawasan perlindungan dan daerah tujuan wisata alam. Selain TWA Danau Buyan memiliki pemandangan alam yang indah, juga kebudayaan berupa cara hidup masyarakat yang unik. Hal tersebut yang menyebabkan TWA Danau Buyan dinilai cocok sebagai daerah pengembangan ekowisataa (BKSDA Bali, 2016). Berdasarkan data pada Balai KSDA Bali, pada tahun 2018 jumlah wisatawan yang berkunjung sebesar 45.924 orang, pada tahun 2019 meningkat menjadi 118.803 orang. Kondisi tersebut ke depan dikhawatirkan dapat berpengaruh pada keseimbangan ekosistem kawasan TWA Danau Buyan. Ekowisata merupakan alternatif yang baik untuk mengembangkan potensi wisata TWA Danau Buyan sebagai produk wisata yang dapat mendatangkan keuntungan ekonomi namun tetap memerhatikan kondisi kelestarian lingkungan (Blumstein, 2017). Dengan adanya penelitian ini diharapkan pihak pengelola khususnya Balai KSDA Bali dapat memperoleh masukan berupa strategi pengelolaan lingkungan untuk pengembangan ekowisata di TWA Danau Buyan, sehingga diharapkan kedua fungsi ekonomi dan ekologis tersebut berjalan beriringan dan sinergis untuk pengoptimalan pengembangan tersebut diperlukan rencana dan strategi.

\section{METODOLOGI}

\subsection{Lokasi Penelitian}

TWA Danau Buyan Tamblingan dahulu merupakan kaldera besar terletak di dua desa yaitu Desa Pancasari, dan Desa Wanagiri. Kecamatan Sukasada, Kabupaten Buleleng, Provinsi Bali (Gambar 1). Kedua danau tersebut terkenal dengan sebutan danau kembar, danau Tamblingan mengapit danau Buyan di sebelah barat, dan danau beratan berada di sebelah timur. Kegiatan penyebaran kuesioner, wawancara dan observasi sosial pada penelitian ini dilakukan pada bulan Desember 2019 sampai dengan Maret 2020.

\subsection{Jenis dan Sumber Data}

Ada dua jenis data yang dikumpulkan yaitu data kualitatif dan data kuantitatif. Data kualitatif adalah data yang didapatkan dari pengunjung/responden berupa informasi dan keterangan yang dapat menggambarkan karakteristik serta dapat mendukung penelitian. Data tersebut dapat berupa hasil wawancara, kuesioner dan informasi lainnya. Kuesioner, wawancara, dan data observasi yang berisi seluruh informasi terkait pengunjung dan masyarakat lokal akan dianalisis secara deskriptif. Sedangkan data kualitatif yang akan dicari terdiri dari, pendapat pengunjung dan masyarakat tentang pelestarian SDA di TWA Danau Buyan, pendapat pengunjung dan masyarakat tentang kebijakan pengelolaan, persepsi pengunjung tentang kelembagaan pengelolaan TWA Danau Buyan, pendapat pengunjung dan masyarakat terhadap kondisi sarana dan prasarana tentang aktivitas wisata yang ada di TWA Danau Buyan. Data kuantitatif dalam penelitian ini antara lain seperti : pertama, data jumlah penduduk, data jenis pendidikan, data jenis mata pencaharian dapat diperoleh (Badan Pusat Statistik), data jumlah kunjungan wisatawan (Balai KSDA Bali), data obyek daya tarik wisata (Dinas Pariwisata Provinsi dan KPH UPTD Bali Utara), data lahan kritis 
yang termasuk pada Bali Bali Bagian Utara (BPDAS Unda Anyar).

\subsection{Penentuan Sampel}

Penentuan sampel untuk analisis persepsi pengunjung TWA Danau Buyan dilakukan dengan accidental sampling, dengan pertimbangan antara lain sampel diambil secara kebetulan memiliki kecocokan sebagai sumber data.

Berdasarkan data pada Balai KSDA Bali jumlah kunjungan wisatawan selama tahun 2019 adalah sebesar 118.803 orang, dengan besarnya jumlah wisatawan tersebut peneliti mengambil sampel dengan menggunakan metode slovin, dengan rumus sebagai berikut ;

$$
\mathrm{n}=\frac{N}{1+N e^{2}}
$$

Sebagai keterangan persamaan di atas, $\mathrm{n}$ merupakan jumlah sampel minimal, $\mathrm{N}$ merupakan populasi, dan nilai e adalah error margin/tingkat error. Dengan adanya margin error ini peneliti dapat memenuhi syarat menetapkan besar sampel minimal (Sugiyono, 2011). Berdasarkan metode slovin, dengan standar error/tingkat kesalahan sebesar $10 \%$, pada tahun 2019 jumlah populasi kunjungan sebesar 118.000 orang sehingga pada lokasi penelitian diambil responden wisatawan sejumlah 302 orang.

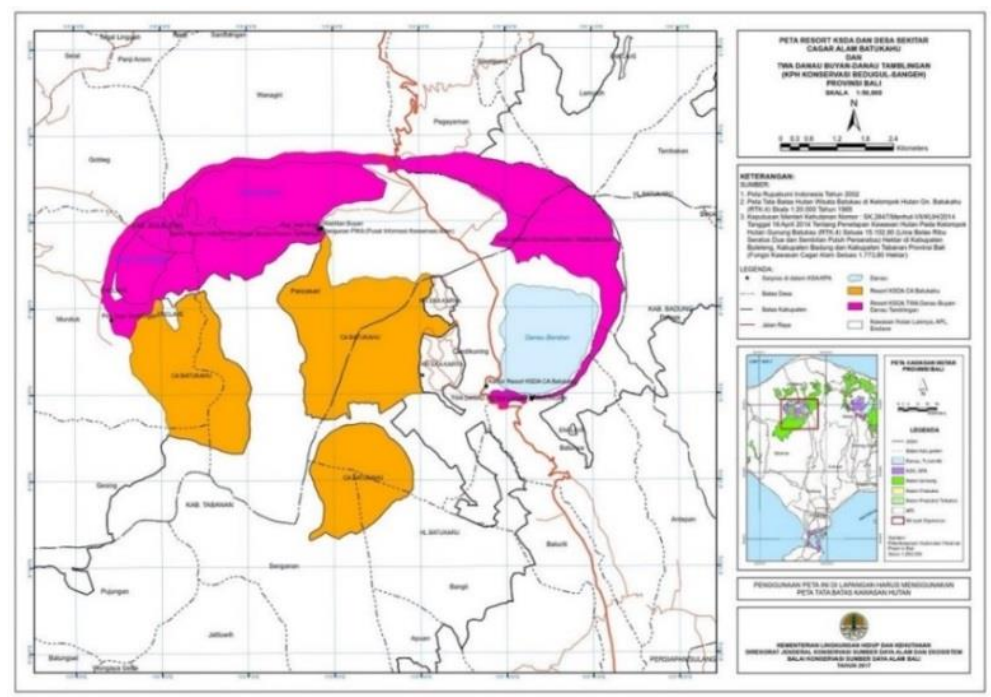

Gambar 1.

Peta Resort KSDA dan desa sekitar Cagar Alam Batukahu dan TWA Danau Buyan-Danau Tamblingan (KPH Konservasi Bedugul-Sangeh) Provinsi Bali

\subsection{Instrumen Penelitian}

Penelitian ini memerlukan piranti /alat dalam mengambil data, adapun alat tersebut panduan kuesioner. Kamera dan alat perekam/alat tulis juga diperlukan agar kegiatan penelitian dapat terdokumentasikan dengan baik. Informasi dari pihak pengelola dapat dilakukan dengan pedoman wawancara. Instrumen penelitian ini dapat dijabarkan pada Tabel 1.

Tabel 1. Instrumen Penelitian

\begin{tabular}{llll}
\hline No. & \multicolumn{1}{c}{ Pertanyaan } & \multicolumn{1}{c}{ Metode } & \multicolumn{1}{c}{ Instrumen } \\
\hline 1. & Persepsi pengunjung dalam pengelolaan dan & Analisis persepsi & Kuesioner dan \\
& atraksi TWA Danau Buyan & & Wawancara \\
2. & Persepsi pengelola kawasan dan masyarakat sekitar persepsi & Pedoman wawancara \\
3. & Analisis strategi pengelolaan lingkungan yang & Wawancara & Blangko Wawancara \\
& mendukung ekowisata & & dan matrix SWOT \\
\hline
\end{tabular}




\subsection{Teknik Pengumpulan Data}

\subsubsection{Teknik penentuan informan}

Menurut Idrus (2007), informan adalah subyek penelitian, yaitu orang memberikan informasi tentang data yang akan diperoleh oleh peneliti. Dalam penelitian ini informan ditentukan dengan teknik purposive sampling, yaitu suatu teknik pengambilan sampling yang digunakan peneliti jika memiliki informasi tertentu dalam pengambilan sampelnya. Informan dipilih dari pihak pengelola, masyarakat, tetua adat atau kelihan banjar, serta pengunjung. sebagai contoh adalah polisi kehutanan dan pengurus desa/banjar setempat. Total jumlah informan yang diwawancarai ada 10 orang.

\subsubsection{Teknik dan Panduan Wawancara}

Metode wawancara dilakukan melalui proses percakapan dengan maksud untuk mengetahui semua kejadian, kegiatan, organisasi, motivasi, dan lainnya sehingga dapat menunjang informasi bagi penelitian ini. Wawancara digunakan pada informan dengan menggunakan panduan wawancara. Wawancara tak terstruktur (pedoman wawancara) digunakan dalam penelitian ini memuat garis besar pertanyaan. Dalam hal ini peneliti membuat catatan yang mendeskripsikan data yang akan ditanyakan. Wawancara pada penelitian ini dilakukan kepada informan dan pengelola dengan menggunakan teknik purposive sampling. Hal tersebut mempertimbangkan bahwa pengelola dan informan sudah dikenal dan diketahui oleh masyarakat setempat.

\subsubsection{Teknik Observasi}

Metode yang digunakan digunakan untuk melihat dan mengamati perubahan fenomena-fenomena sosial yang tumbuh dan berkembang di masyarakat pada lokasi penelitian disebut metode observasi. Metode ini digunakan untuk mengecek data yang diperoleh dari informan. Pengecekan data tersebut dilakukan secara langsung melihat peristiwa-peristiwa kejadian-kejadian yang terjadi di masyarakat, lingkungan, dan gejalagejala yang terjadi terutama yang berkaitan dengan variabel penelitian. Dalam metode ini peneliti menjadi anggota penuh dari lingkungan TWA Danau Buyan yang diamati.

\subsubsection{Teknik Survei dan Kuesioner}

Metode mengumpulkan informasi data primer disebut dengan survai. Survei ini dilakukan sebelum membahas dan menyusun kuesioner yang akan digunakan dalam penelitian (Singariumbun dan Effendi, 1995; Nugroho, 2018). Pada penelitian deskriptif seperti ini, peneliti menggunakan pertimbangan memilih variabel terpenting yang didasari pada tujuan penelitian. Dengan pertimbangan variabel utama adalah untuk mendeskripsikan potensi daya tarik ekowisata di TWA Danau Buyan, serta menganalisis persepsi pengunjung terhadap kegiatan ekowisata di TWA Danau Buyan. Peneliti menyusun pertanyaan yang bersifat spesifik sehingga bisa didapatkan dengan cukup lengkap. Berdasarkan pertimbangan tersebut variabel turunannya dalam kuisioner adalah: 1) identitas dan karakteristik pengunjung, 2) persepsi wisatawan terhadap fungsi kawasan, 3) persepsi wisatawan tentang kebijakan pengelolaan, 4) persepsi wisatawan terhadap aktivitas wisata, 5) persepsi wisatawan terhadap sarana \& prasarana, 6) kriteria dan penilaian daya tarik wisata, 7) persepsi wisatawan terhadap pembayaran bersifat sukarela (willingnes to pay).

\subsection{Teknik Analisis Data}

Data yang telah diperoleh dari penelitian ini dianalisis secara deskriptif kualitatif dan interpretatif. Data yang dideskripsikan dan diinterpretasikan adalah data yang diperoleh melalui teknik pengumpulan data untuk persepsi pengunjung kawasan TWA Danau Buyan, dan hasil analisis SWOT.

Pada awal rencana pada Proposal Penelitian, metode pengumpulan data analisis SWOT dilaksanakan dengan Focus Group Discussion (FGD). Sehubungan adanya pandemi Corona, dan terbitnya surat edaran (SE) Gubernur Bali dengan Nomor.7194 tahun 2020 pada tanggal 16 Maret 2020 tentang Panduan Tindak Lanjut Terkait Pencegahan Penyelamatan Corona Virus Disease 2019 
(Covid -19). Dimana salah satu arahan dalam surat edaran tersebut adalah membatasi kegiatan pengumpulan massa yang salah satunya dalam bentuk FGD, maka kegiatan pengumpulan data untuk analisis SWOT dilakukan dengan metode wawancara secara mendalam.
Diharapkan dalam penelitian ini didapatkan hasil gambaran mengenai strategi pengelolaan lingkungan di TWA Danau Buyan secara akurat dan sesuai dengan data yang ada. Analisis yang dipergunakan dalam penelitian, sebagaimana dijelaskan dalam Tabel 2.

Tabel 2. Metode Analisis Data

No.

Tujuan Penelitian

Sumber Data

Teknik Analisis Data

1. Analisis persepsi pengunjung terhadap kawasan TWA Danau Buyan

2. Analisis Persepsi Pengelola Kawasan dan Masyarakat Sekitar

3. Menyusun strategi dalam mengembangkan kawasan TWA Danau Buyan berdasarkan faktor internal dan eksternal

$\begin{array}{ll}\text { Data Sekunder : Kondisi fisik } & \text { Kuesioner } \\ \text { yang terdapat di TWA Danau } & \text { Deskriptif } \\ \text { Buyan } & \end{array}$

Data Primer : Survei dan hasil

kuesioner

Data Primer : Wawancara Kuesioner

langsung deskriptif

Data Primer : wawancara Analisis SWOT secara mendalam dan survei.

\subsubsection{Analisis Strategi dan Pengelolaan Lingkungan}

Analisis SWOT digunakan dalam penentuan strategi pengelolaan lingkungan di kawasan Danau Buyan. Strategi pengelolaan lingkungan dalam penelitian ini dilakukan berdasarkan analisis SWOT. Analisis SWOT menurut Rangkuti (2006) merupakan singkatan dari lingkungan dalam yaitu strengths dan weaknesses, serta lingkungan luar yaitu Opportunities dan Threaths yang dihadapi sebuah organisasi. Analisis SWOT adalah metode dalam membandingkan antara faktor eksternal Peluang (Opportunities) dan Ancaman (Threaths) dengan faktor internal kekuatan (Strengths) dengan kelemahan (Weaknesses). Empat kelompok strategi yang dipilih dalam matrik SWOT menurut Rangkuti 1997 adalah sebagai berikut:

1. Kelompok strategi yang memiliki tujuan untuk mengatasi sebanyak mungkin hambatan yang timbul dengan tidak menonjolkan kelemahan organisasi disebut strategi WT (Weaknesses-Threats).

2. Kelompok yang memiliki strategi yang memiliki tujuan untuk memanfaatkan semaksimal mungkin peluang yang ada dan mencegah melemahnya posisi organisasi dengan menutupi sebanyak mungkin kelemahan organisasi disebut strategi WO (WeaknessesOpportunities).

3. Kelompok strategi yang memiliki tujuan untuk mengatasi hambatan yang timbul dengan mengandalkan kekuatan organisasi semaksimal mungkin disebut strategi ST (Strengths Threaths).

4. Kelompok strategi yang memiliki tujuan untuk memperkuat organisasi dalam persaingan dengan cara memanfaatkan kekuatan organisasi sebesar-besarnya agar dapat memperoleh peluang pasar seluasluasnya disebut strategi SO (Strengths - Opportunities).

Tahapan penyusunan strategi managemen ini dikerjakan sebelum menetapkan tujuan pemasaran yang hendak dicapai. Analisis SWOT dapat digunakan sebagai faktor pembanding antara faktor dalam yaitu kelemahan dan kekuatan dengan faktor luar yaitu peluang dan ancaman yang efektif dan mumpuni. Jadi suatu hal yang mutlak dalam pelaksanaanya diperlukan pelibatan seluruh stakeholder yang ada, baik itu masyarakat lokal, pengunjung, pengelola, 
pihak desa/banjar, pemerintah kecamatan dan pemerintah kabupaten.

\subsubsection{Pengklasifikasian data berdasarkan faktor dalam dan faktor luar.}

IFE (Internal Factor Analysis) dan EFE (Eksternal Factor Analysis) dijabarkan dalam bentuk matrik. Matrik IFE dipergunakan dalam menganalisis faktorfaktor dalam suatu obyek wisata yang terkait dengan kekuatan dan kelemahan, sedangkan matrik EFE digunakan untuk menganalisis peluang dan ancaman yang dapat berpengaruh dalam pengembangan kawasan TWA Danau Buyan. Proses awal yaitu membuat matrik IFE dan EFE dengan cara sebagai berikut:

1. Data penelitian yang sudah diperoleh diklasifikasikan berdasarkan faktor dalam (kelemahan dan kekuatan) dan faktor luar (ancaman dan peluang).

2. Hasil pengklasifikasian tersebut kemudian diberikan nilai bobot yang dimulai dari skala 0.0 (tidak penting) hingga 1.0 (sangat penting). Jumlah semua bobot yang diberikan tidak diperkenankan lebih dari nilai skor 1.0, sedangkan nilai rating pada data tersebut diberikan dari nilai tertinggi atau paling berpengaruh dengan nilai rating 4, hingga nilai rating 1 atau tidak berpengaruh. IFE Matrik dapat dilihat pada Tabel 3.

Tabel 3. IFE Matrik

\begin{tabular}{|c|c|c|c|}
\hline $\begin{array}{c}\text { Faktor Strategi } \\
\text { Internal }\end{array}$ & Bobot & Rating & $\begin{array}{c}\text { Bobot } x \\
\text { Rating } \\
\text { (Skor) }\end{array}$ \\
\hline $\begin{array}{l}\text { Kelemahan } \\
\text { (weaknesses) } \\
\text { Kekuatan } \\
\text { (strengths) } \\
\text { TOTAL }\end{array}$ & & & \\
\hline
\end{tabular}

3. Menentukan data faktor eksternal dengan melakukan perlakuan sama pada faktor internal tersebut di atas (Tabel 4);

Proses selanjutnya adalah memetakan dari masing-masing pengurangan matriks IFE dan $\mathrm{EFE}$ dalam sumbu $\mathrm{X}$ dan $\mathrm{Y}$ agar mengetahui secara pasti posisi strategis yang sesungguhnya (Rangkuti, 2005). Adapaun tahapan adalah sebagai berikut:

1. Sumbu $X$ merupakan garis dalam kuadran SWOT yang mempresentasikan pengurangan skor faktor kekuatan dan kelemahan dalam matrik IFE.

2. Sedang matrik kuadran SWOT sumbu Y mempresentasikan pengurangan antara faktor peluang dengan ancaman dalam matrik EFE.

3. Selanjutnya dalam bagan matrik SWOT yang mempresentasikan strategi pengembangan ditunjukan oleh titik $(\mathrm{X}, \mathrm{Y})$.

Tabel 4. EFE Matrik

\begin{tabular}{|c|c|c|c|}
\hline $\begin{array}{c}\text { Faktor } \\
\text { Strategi } \\
\text { Internal }\end{array}$ & Bobot & Rating & $\begin{array}{l}\text { Bobot* } \\
\text { Rating } \\
\text { (Skor) }\end{array}$ \\
\hline $\begin{array}{l}\text { Ancaman } \\
\text { (theraths) } \\
\text { Peluang } \\
\text { (opportunites) } \\
\text { TOTAL }\end{array}$ & & & \\
\hline
\end{tabular}

\subsubsection{Matriks Internal dan Eksternal}

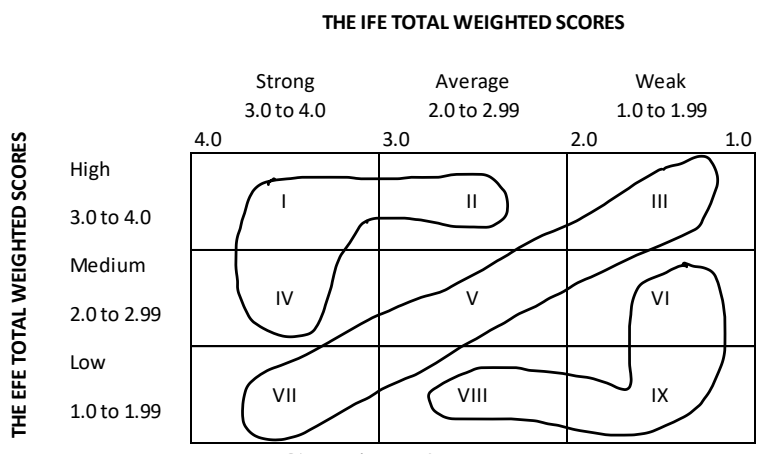

Gambar 2.

Matriks Internal-Eksternal (David, 2017)

Internal-External Matrix berdasarkan pada 2 (dua) dimensi, yaitu : (1) IFE nilai total berdasarkan $x$-axis dan (2) EFE total nilai pada y-Axis. Di samping memiliki 9 sel bagian (kuadran), IE matrix memiliki 3 bagian wilayah, yang memiliki 3 penerapan strategi yang berbeda, sebagaimana diterangkan di bawah ini:

- Wilayah I, mencakup sel bagian I (kesatu), II (kedua), dan IV (keempat) digambarkan sebagai tahapan pertumbuhan, penetrasi pasar, 
pengembangan produk, dan pengembangan pasar. Tahapan ini paling baik menerapkan pola strategi intensif integratif atau dapat disebut tahapan strategi yang mendalam dan kesegala arah. Bagian ini adalah bagian terbaik dengan nilai IFE dan EFE dengan skor tertinggi. Suatu organisasi yang sukses dapat mencapai portfolio bisnisnya dalam wilayah I.

- Wilayah II, mencakup sel bagian III (ketiga), V (kelima), atau VII (ketujuh) digambarkan sebagai strategi pada tahap bertahan dan memelihara, kegiatan pengembangan produk dan penetrasi pasar adalah kegiatan yang sesuai dilakukan pada tahap ini.

- Wilayah III, mencakup sel bagian VI (keenam), VIII (kedelapan), atau IX (kesembilan) dapat dijabarkan sebagai strategi pemanenan dan pelepasan.

\subsubsection{Matriks SWOT}

Analisis SWOT memiliki empat komponen yaitu :'kelemahan', 'Kekuatan', 'ancaman', 'peluang'. Kelemahan dan kekuatan adalah faktor dalam dan atribut organisasi, sedangkan ancaman dan peluang adalah faktor luar dan merupakan atribut lingkungan hidup. Analisis SWOT dijabarkan dalam empat kuadran yang diatur menurut empat judul bagian.

Matriks SWOT dapat dijabarkan sebagai alat untuk menerangkan atau mendeskripsikan strategi-strategi yang dapat diambil dalam suatu tahapan organisasi, di antaranya strategi WO (kelemahan peluang), strategi SO (kekuatan peluang), strategi ST (kekuatan ancaman), dan strategi WT (kelemahan ancaman).

\section{HASIL DAN PEMBAHASAN}

\subsection{Hasil}

Dari keseluruhan hasil analisis persepsi wisatawan terhadap TWA Danau Buyan adalah cukup baik. Persepsi pengunjung dianalisis berdasarkan pada variabel persepsi wisatawan terhadap fungsi kawasan, kebijakan pengelolaan, aktivitas wisata, sarana dan prasarana, dan terhadap willingness to pay dapat disimpulkan dari 302 responden berpendapat bahwa TWA Danau Buyan selain memiliki fungsi rekreasi juga memiliki fungsi lainnya. Pada variabel pengelolaan kebijakan sebanyak $40 \%$ wisatawan mengetahui Undang-Undang terkait kehutanan dan menganggap bahwa pembuatan rencana pengelolaan penting sebanyak $37 \%$. Sedangkan atraksi yang menjadi tujuan utama aktivitas wisata adalah camping sebesar $40 \%$, dengan tujuan utama untuk menikmati danau dan landscape. Persepsi wisatawan terhadap sarana dan prasarana dasar adalah cukup kecuali untuk tempat sampah dan tempat ibadah. Berdasarkan hasil kuesioner terhadap pengunjung willingness to pay atau disebut kesediaan wisatawan untuk membayar adalah sebesar 86\%, dengan jumlah kisaran harga Rp.5000-Rp.10.000.

Motivasi utama wisatawan berkunjung ke TWA Danau Buyan adalah untuk berkemah atau berselfie serta menikmati keindahan alam berupa landscape dan danau di TWA Buyan. Wisatawan pada umumnya datang bersama teman dan rombongan. Untuk kondisi jalan dan aksesibiltas dari pusat Denpasar ke lokasi dalam keadaan bagus dan dapat ditempuh kurang lebih 2 jam. Untuk fasilitas sarana dan prasarana penunjang yang ada di TWA Danau Buyan dinilah cukup baik, namun begitu ada beberapa hal yang masih dirasa kurang yaitu kurangnya sarana ibadah (selain hindu), kamar kecil atau toilet, tempat sampah, kios cinderamata, dan ruang informasi. Dan yang tak kalah penting adalah baliho yang menjelaskan bahwa kawasan ini merupakan kawan yang ditetapkan sebagai kawasan yang bukan hanya sebagai sarana rekreasi juga sebagai fungsi perlindungan ekosistem flora dan fauna berdasarkan perundang-undangan yang berlaku. Sampai dengan saat ini wisatawan hanya membayar sebesar Rp.5000 (wisatawan lokal), dan Rp.100.000 (wisatawan asing) untuk tiket masuk ke kawasan. Salah satu aspek yang cukup penting dan perlu diperhatikan oleh pihak pengelola adalah tentang kenyamanan wisatawan, pada umumnya wisatawan memiliki pengalaman positif terhadap keberadaan kawasan TWA Danau Buyan. Pengalaman positif tersebut ditentukan antara lain oleh tingkat 
kenyamanan pengunjung yang berbanding (strengths), kelemahan (weakness), peluang lurus dengan kondisi fisik dan kebersihan (opportunity), dan ancaman (threat). Pada fasilitas wisata.

Ada 4 (empat) aspek dalam analisis Tabel 5 berikut akan dijabarkan aspek-aspek tersebut.

SWOT yang diperhatikan yaitu kekuatan

Tabel 5. Faktor-faktor internal dan eksternal dalam pengembangan Ekowisata TWA Danau Buyan

\begin{tabular}{|c|c|}
\hline No. & Uraian \\
\hline 1. & Faktor Lingkungan Internal \\
\hline & $\begin{array}{l}\text { a. Kekuatan } \\
\text { 1. Keunikan landscape dan tipe ekosistem beserta flora, fauna yang masih alami yang } \\
\text { sangat berpotensi sebagai obyek daya tarik wisata. } \\
\text { 2. Sebagai kawasan catchment area bagi kabupaten Buleleng dan kawasan di bawahnya } \\
\text { (kawasan catur angga). } \\
\text { 3. Sebagai kawasan yang dianggap suci bagi masyarakat sekitar karena banyaknya } \\
\text { keberadaan pura di kawasan tersebut. } \\
\text { 4. Tingginya dukungan pemerintah baik itu pusat dan daerah di sekitar kawasan tersebut, } \\
\text { hal tersebut dibuktikan dengan banyaknya pelatihan dan pemebntukan kelompok- } \\
\text { kelompok seperti kelompok tani, kelompok trekking, kelompok selfie, koperasi, dan } \\
\text { kelompok pemandu wisata. } \\
\text { 5. Telah teridentifikasi obyek dan daya tarik wisata, baik atraksi alam maupun atraksi } \\
\text { budaya termasuk dalam KSPN Bali utara. } \\
\text { b. Kelemahan } \\
\text { 1. Keterbatasan sarana dan prasarana penunjang ekowisata. } \\
\text { 2. Masyarakat belum seluruhnya menikmati hasil usaha wisata karena secara resmi masih } \\
\text { dikelola oleh Balai KSDA (perizinan kerjasama cukup sulit). } \\
\text { 3. Kurangnya tenaga kebersihan dan pengamanan hutan. } \\
\text { 4. Kurangnya sosialisasi dan pelibatan masyarakat terhadap Pengelolaan TWA Danau } \\
\text { Buyan. } \\
\text { 5. Pengembangan unsur seni dan budaya masyarakat yang belum optimal. } \\
\text { 6. Terbatasnya paket wisata yang berintegrasi dari BKSDA \& Unit pengelola kerjasama } \\
\text { masyarakat sekitar. } \\
\text { 7. Pengelolaan sampah yang belum optimal }\end{array}$ \\
\hline 2 & Faktor Lingkungan Eksternal \\
\hline & $\begin{array}{l}\text { a. Peluang } \\
\text { 1. Membuka lapangan pekerjaan bagi masyarakat sekitar. } \\
\text { 2. Menambah pendapatan/income masyarakat sekitar (dengan adanya kerjasma/MoU } \\
\text { dengan masyarakat sekitar). } \\
\text { 3. Sebagai lokasi pemersatu desa sekitarnya/catur desa penyangga kawasan. } \\
\text { 4. Sebagai sekolah hidup bagi pelajar dan pengunjung kawasan TWA Danau Buyan } \\
\text { Tersebut. } \\
\text { 5. Sebagai Katalisator pembentukan kelembagaan bagi masyarakat sekitar. } \\
\text { 6. Wisatawan mempunyai persepsi postif terhadap upaya pengembangan ekowisata di } \\
\text { TWA Danau Buyan. } \\
\text { 7. Potensi sebagai lokasi wisata spiritual } \\
\text { b. Ancaman } \\
\text { 1. Kerusakan lingkungan akibat penangkapan satwa dan pengambilan tanaman di dalam } \\
\text { kawasan. } \\
\text { 2. Masih adanya penggunaan pestisida dan herbisida bagi pengelolaan pertanian di sekitar } \\
\text { danau. } \\
\text { 3. Karena topografi kelerengan hutan di sekitar TWA Danau Buyan yang cukup terjal } \\
\text { dapat memberi ancaman berupa erosi, pendangkalan danau, dan banjir apabila hujan } \\
\text { lebat. }\end{array}$ \\
\hline
\end{tabular}


Dari tabel IFE (Internal factor analysis) dan tabel EFE (Eksternal factor analysis) sebagaimana dalam tabel 5 di atas dirangkum dan dijabarkan ke dalam matrik analisis SWOT yang dijelaskan pada Tabel 6.

Berdasarkan IE matrik strategi pengelolaan lingkungan di TWA Danau Buyan dan Tamblingan termasuk kedalam divisi sel $\mathrm{V}$ atau Hold and Maintain atau dapat digambarkan sebagai strategi pada tahap bertahan dan memelihara, penetrasi pasar/promosi, serta variasi produk. Strategi tersebut antara lain meliputi : a) Mengembangkan potensi keunikan di TWA Danau Buyan baik itu potensi sumberdaya alam seperti keanekaragaman hayati (flora dan fauna), keindahan landscape, dan potensi sosial budaya masyarakat yang dapat dikembangkan dan dikemas menjadi satu paket ekowisata, b) Meningkatkan dukungan dari pemerintah pusat, daerah, dan masyarakat lokal sehingga dapat mengoptimalkan peningkatan kualitas ODTW TWA Danau Buyan baik itu sarana dan prasarana pariwisata, fasilitas publik, sumber daya manusia, dan meningkatkan promosi wisata spiritual maupun budaya c) Meningkatkan pengawasan di lapangan, peningkatan pembinaan dan sosialisasi tentang manfaat obyek wisata kepada masyarakat, serta mengajak masyarakat dan wisatawan untuk berpartisipasi aktif dalam menjaga kelestarian TWA Danau Buyan serta bekerjasama dengan berbagai pihak d) Membangun kerjasama dengan seluruh stakeholder yang berkompeten antara lain yaitu Balai KSDA, Dinas Pariwisata, Dinas Pertanian, Akademis, LSM, organisasi masyarakat dan adat setempat dan membuka peluang kerjasama dengan masyarakat sekitar.

Tabel 6. Hasil Analisis Matrix SWOT Strategi Pengelolaan Lingkungan di Danau Buyan di Kabupaten Buleleng

\begin{tabular}{|c|c|c|}
\hline Eksternal Faktor & $\begin{array}{l}\text { Kekuatan (Strength) } \\
\text { 1. Keunikan landscape dan tipe ekosistem } \\
\text { beserta flora, fauna yang masih alami } \\
\text { yang sangat berpotensi sebagai obyek } \\
\text { daya tarik wisata. } \\
\text { 2. Sebagai kawasan catchment area bagi } \\
\text { kabupaten Buleleng dan kawasan di } \\
\text { bawahnya (kawasan catur angga). } \\
\text { 3. Sebagai kawasan yang dianggap suci } \\
\text { bagi masyarakat sekitar karena } \\
\text { banyaknya keberadaan pura di kawasan } \\
\text { tersebut. } \\
\text { Tingginya dukungan pemerintah baik } \\
\text { itu pusat dan daerah di sekitar kawasan } \\
\text { tersebut, hal tersebut dibuktikan } \\
\text { dengan banyaknya pelatihan dan } \\
\text { pemebntukan kelompok-kelompok } \\
\text { seperti kelompok tani, kelompok } \\
\text { trekking, kelompok selfie, koperasi, } \\
\text { dan kelompok pemandu wisata. } \\
\text { Telah teridentifikasi obyek dan daya } \\
\text { tarik wisata, baik atraksi alam maupun } \\
\text { atraksi budaya termasuk dalam KSPN } \\
\text { Bali utara. }\end{array}$ & $\begin{array}{l}\text { Kelemahan (Weakness) } \\
\text { 1. Keterbatasan sarana dan prasarana } \\
\text { penunjang ekowisata. } \\
\text { 2. Perizinan kerjasama antara masyarakat } \\
\text { dan pihak pengelola masih sulit, } \\
\text { sehingga masyarakat belum seluruhnya } \\
\text { menikmati hasil usaha. } \\
\text { 3. Kurangnya tenaga kebersihan dan } \\
\text { pengamanan hutan. } \\
\text { 4. Kurangnya sosialisasi dan pelibatan } \\
\text { masyarakat terhadap Pengelolaan } \\
\text { TWA Danau Buyan. } \\
\text { 5. Pengembangan unsur seni dan budaya } \\
\text { masyarakat yang belum optimal. } \\
\text { Terbatasnya paket wisata yang } \\
\text { berintegrasi dari BKSDA \& Unit } \\
\text { pengelola kerjasama masyarakat } \\
\text { sekitar. } \\
\text { Pengelolaan sampah yang belum } \\
\text { optimal. }\end{array}$ \\
\hline $\begin{array}{l}\text { Peluang (Opportunities) } \\
\text { 1. Membuka lapangan pekerjaan bagi } \\
\text { masyarakat sekitar. } \\
\text { 2. Menambah pendapatan/income } \\
\text { masyarakat sekitar. } \\
\text { 3. Sebagai lokasi pemersatu desa } \\
\text { sekitarnya/catur desa penyangga } \\
\text { kawasan. } \\
\text { 4. Sebagai sekolah hidup bagi pelajar } \\
\text { dan pengunjung kawasan TWA } \\
\text { Danau Buyan Tersebut. } \\
\text { 5. Sebagai Katalisator pembentukan } \\
\text { kelembagaan bagi masyarakat } \\
\text { sekitar. } \\
\text { 6. Wisatawan mempunyai persepsi } \\
\text { postif terhadap upaya pengembangan }\end{array}$ & $\begin{array}{l}\text { Strategi S-O } \\
\text { Mengembangkan potensi keunikan di TWA } \\
\text { Danau Buyan baik itu potensi sumberdaya } \\
\text { alam seperti keanekaragaman hayati (flora } \\
\text { dan fauna), keindahan landscape, dan potensi } \\
\text { sosial budaya masyarakat yang dapat } \\
\text { dikembangkan dan dikemas menjadi satu } \\
\text { paket ekowisata. Melakukan promosi secara } \\
\text { intensif melalui media masa, media } \\
\text { elektronik, dan melalui internet. }\end{array}$ & $\begin{array}{l}\text { Strategi W-O } \\
\text { Mengoptimalkan dukungan dari pemerintah } \\
\text { pusat, daerah dan masyarakat lokal sehingga } \\
\text { dapat meningkatkan kualitas ODTW TWA } \\
\text { Danau Buyan baik itu sarana dan prasarana, } \\
\text { fasilitas, publik, sumber daya manusia, dan } \\
\text { meningkatkan promosi wisata spiritual } \\
\text { maupun budaya. Pembuatan paket outbond, } \\
\text { paket ekowisata yang mencakup menikmati } \\
\text { alam dan hasil agrowisata, pengamatan } \\
\text { satwa, lomba foto satwa dan keindahan } \\
\text { landscape. Meningkatkan keaktifan dan } \\
\text { pengembangan pembuatan industri rumah } \\
\text { tangga seperti pernak pernik/Souvenir yang } \\
\text { memiliki ciri khas kawasan. }\end{array}$ \\
\hline
\end{tabular}




\begin{tabular}{|c|c|c|}
\hline $\begin{array}{l}\text { ekowisata di TWA Danau Buyan, } \\
\text { serta meningkatnya tren kunjungan } \\
\text { pada kegiatan yang berbasis } \\
\text { pelestarian alam } \\
\text { 7. Potensi Sebagai Lokasi Wisata } \\
\text { Spiritual }\end{array}$ & & \\
\hline $\begin{array}{l}\text { Ancaman (Threat) } \\
\text { 1. Kerusakan lingkungan akibat } \\
\text { penangkapan satwa dan pengambilan } \\
\text { tanaman di dalam kawasan. } \\
\text { 2. Masih adanya penggunaan pestisida } \\
\text { dan herbisida bagi pengelolaan } \\
\text { pertanian di sekitar danau. } \\
\text { 3. Karena topografi kelerengan hutan di } \\
\text { sekitar TWA Danau Buyan yang } \\
\text { cukup terjal dapat memberi ancaman } \\
\text { berupa erosi, pendangkalan danau, } \\
\text { dan banjir apabila hujan lebat. }\end{array}$ & $\begin{array}{l}\text { Strategi S-T } \\
\text { Meningkatkan pengawasan di lapangan, } \\
\text { peningkatan pembinaan pendampingan, dan } \\
\text { penyuluhan maupun sosialisasi tentang } \\
\text { manfaat obyek wisata kepada masyarakat, } \\
\text { serta mengajak wisatawan maupun } \\
\text { masyarakat untuk berpartisipasi aktif dalam } \\
\text { menjaga kelestarian TWA yang ada } \\
\text { (kegiatan wisata yang ramah lingkungan). } \\
\text { Bekerjasama dengan berbagai pihak agar } \\
\text { menerapkan teknik konservasi tanah dan air } \\
\text { sehingga laju erosi pada lereng-lereng di } \\
\text { sekitar Kawasan berkurang, serta } \\
\text { mengenalkan dan memberi pelatihan } \\
\text { pembuatan pupuk organik bagi petani sekitar } \\
\text { kawasan. }\end{array}$ & $\begin{array}{l}\text { Strategi W-T } \\
\text { Membangun kerjasama dengan stakeholder } \\
\text { yang berkompeten antara lain yaitu Balai } \\
\text { KSDA,Dinas Pariwisata, Dinas Pertanian, } \\
\text { Akademis, LSM, organisasi masyarakat dan } \\
\text { adat setempat. Memberikan pembinaan dan } \\
\text { membuka peluang kerjasama pengembangan } \\
\text { kawasan wisata mulai dari perencanaan, } \\
\text { sampai pada tahap pengelolaan kawasan } \\
\text { wisata agar kawasan dapat memberikan } \\
\text { manfaat ekonomi, sosial, budaya bagi } \\
\text { masyarakat sekitar dan tetap menjaga } \\
\text { kelstarian. }\end{array}$ \\
\hline
\end{tabular}

\subsection{Pembahasan}

Dampak untuk kegiatan ekowisata terhadap lingkungan di kawasan TWA Danau Buyan adalah sebagai berikut:

\section{Dampak bagi upaya pelestarian lingkungan konservasi}

Berdasarkan hasil kuesioner di dapatkan bahwa pengunjung sadar TWA Danau Buyan juga memiliki fungsi lain selain sebagai fungsi rekreasi. Pengunjung pada umumnya berpendapat bahwa danau bersih dan jernih, serta hutan dan alam masih terjaga dengan baik. Selain konservasi alam konservasi budaya juga dihormati dan diberikan ruang tersendiri pada tatanan sosial masyarakat sekitar kawasan TWA Danau Buyan. Berdasarkan hasil inventarisasi Balai KSDA Bali 2018 ada sekitar 48 buah pura di sekitar kawasan TWA Danau Buyan dan Tamblingan, dimana dalam setiap setiap upacara maupun beribadahan keagamaan masyarkat tetap diperbolehkan masuk kawasan. Seluruh upaya konservasi lingkungan dan budaya ini merupakan bentuk timbal balik masyarakat kawasan terhadap TWA. Danau Buyan Tamblingan karena telah memberikan manfaat ekologis secara langsung maupun tidak langsung. Hasil tangkapan ikan dari danau, rumput pakan ternak, dan penghasilan dari berjualan dan penyediaan jasa termasuk dalam manfaat langsung, sedangkan untuk manfaat tidak langsung adalah terjaganya lingkungan dan cadangan air danau. Selain itu kawasan TWA Danau Buyan Tamblingan juga memegang peranan penting bagi pengembangan ekowisata di kawasan sekitarnya, seperti sektor agrowisata (di Desa Pancasari dan Wanagiri), pelestarian Subak Alon /subak lahan kering di Desa Wanagiri, penanaman kopi di sela-sela hutan kemasyarakatan. Dalam dokumen design tapak oleh KPTDH Bali utara (2019) faktorfaktor penting yang menjadi pertimbangan dalam pelestarian lingkungan adalah tidak menggangu lintasan satwa, Menghadirkan nilai-nilai lokalitas, penggunaan bahan bangunan yang sehat dan ramah lingkungan, dan menekan serendah mungkin hal yang menimbulkan limbah. Faktor-faktor tersebut harus diperhatikan dalam pengembangan suatu obyek wisata yang mempertimbangkan stakeholder kawasan tersebut.

\section{Dampak Partisipasi Masyarakat dan Kelembagaan}

Keberhasilan pengelolaan suatu kawasan tidak dapat terlepas dari upaya pihak pengelola merangkul seluruh komponen masyarakat yang ada. Masyarakat sekitar yang berada di zona penyangga kawasan TWA Danau Buyan -Tamblingan sendiri bukan sebagai obyek tetapi juga subyek dari pengelolaan kawasan. Partisipasi masyarakat dalam beberapa aspek telah terjalin cukup baik dengan melalui mekanisme Perjanjian 
Kerjasama/ MoU (Momorandum of Understanding) antara lain kelompok trekking di Desa wanagiri, kelompok pemandu wisata di Desa Pancasari, kelompok tani di Desa Candi Kuning. Beberapa Kelembagaan masyarakat yang ada di desa penyangga terebut antara lain sebagai berikut : BPD (Badan Pengawas Desa), LPM (Lembaga Pemberdayaan Masyarakat), Linmas (Perlindungan Masyarakat), Bumdes (Badan Usaha Milik Desa), Karang Taruna, Pokdarwis (Kelompok Sadar wisata), LPD (Lembaga Perkreditan desa), KTH (Kelompok Tani Hutan), dan Koperasi Jasa Wisata. Semakin berkembangnya desa menjadi desa wisata maka meningkat pula lapangan pekerjaan dan pendapatan masyarakat. Hal tersebut juga mendorong desa menjadi semakin berbenah, dan semakin berkembang. Adanya organisasi juga lebih mempercepat dan memperlancar upaya regenerasi yang ada di masyarakat. Manfaat dari berorganisasi secara umum membantu pemerintah desa sebagai jembatan aspirasi sehingga apa yang diinginkan masyarakat dapat disampaikan dan diimplementasikan ke dalam programprogram pemerintah desa.

\section{Dampak Peningkatan Ekonomi dan} Penghasilan Masyarakat

Pada umumnya masyarakat di Desa Wanagiri dan Pancasari mayoritasnya bekerja sebagai petani dan pekebun. Namun begitu karena adanya peluang peningkatan pendapatan dari sektor wisata, seperti telah dijelaskan pada bab sebelumnya bahwa ada beberapa kerjasama yang dapat meningkatkan pendapatan masyarakat seperti adanya spot foto/ selfie di Desa Wanagiri, dengan pendapatan sebesar Rp. 164.605.000; dari bulan Juni s/d Desember 2019. Hasil penjualan bahan makanan dan toko kelontong di sekitar TWA Danau Buyan sebesar Rp.192.690.000 untuk 4 kios selama tahun 2019. Kendala yang ada barang yang dijual masih kurang beragam, serta belum ada toko cinderamata. Potensi pariwisata yang meningkat maka meningkat pula peluang masyarakat lokasl dalam memperoleh tambahan pendapatan melalui penjualan bahan makanan, penyewaan tenda, dan jasa spot selfie.
Lembaga yang sangat berperan penting bagi pengembangan wisata dan ekonomi di desa adalah BUMDES (Badan Usaha Milik Desa). Berdasarkan wawancara dengan Bapak Made Swartana yang menjabat sebagai ketua BUMDES Desa Pancasari saat ini, dapat dijabarkan struktur organisasi desa tersusun dari ketua, sekretaris dan bendahara. Dalam organisasi BUMDES sendiri ada unit-unit usaha yang bergerak sesuai bidangnya seperti (1)Unit perdagangan, yaitu suatu usaha yang bergerak dibidang perdagangan baik kebutuhan pokok atau sembako, (2) Unit usaha pertanian, yaitu usaha yang bergerak dibidang penjualan usaha pertanian dan perkebunan, (3) Unit pengelola kawasan/pariwisata, yaitu usaha yang bergerak dalam bidang kepariwisataan, (4) Unit usaha simpan pinjam, yaitu usaha dibidang simpan pinjam yang dipergunakan dalam menambah atau memperluas usaha dagang, (5) Jasa penyewaan tenda, yaitu usaha dibidang penyewaan tenda dan peralatan yang disewakan untuk pengunjung di sekitar kawasan TWA Danau Buyan Danau Tamblingan.

Menurut Chania (2017) setelah adanya kegiatan ekowisata yang ada di suatu ODTW akan meningkatkan tingkat pendapatan tambahan bagi informan, walaupun masih ada ketimpangan dan masih tidak merata karena keuntungan peningkatan ekonomi hanya dirasakan langsung oleh pelaku wisata di sekitar kawasn saja. Peningkatan penghasilan masyarakat sekitar kawasan TWA. Danau Buyan -Tamblingan dapat terlihat langsung sebagai contoh untuk pemilik warung, selfie spot, penyewaan tenda yang ada di sekitar lokasi. Disamping itu adanya peningkatan lapangan pekerjaan bagi penduduk lokal dalam usaha-usaha wisata yang ada sekitar lokasi. Sehingga mengurangi berpindahnya pemuda dan pemudi desa ke kota untuk mencari lapangan pekerjaan.

\section{Dampak edukasi dan sosial budaya.}

Secara umum kondisi atraksi di TWA Danau Buyan cukup menarik, namun begitu kapasitas yang ada belum dikembangkan secara optimal. Dari hasil responden yang dihimpun hanya sekitar 60 orang saja yang menjawab bahwa TWA Danau Buyan juga 
berfungsi sebagai lokasi sekolah alam bagi masyarakat sekitar. Hal tersebut mengindikasikan bahwa pengunjung belum dilibatkan secara interaktif terhadap alam dan sosial budaya masyarakat lokal. Kearifan yang berbasis pelestarian alam dan budaya serta nilai yang terkandung dalam kehidupan masyarakat sehari-hari sampai saat ini belum tersampaikan secara efektif kepada pengunjung. Contoh seni budaya yang cukup menonjol dan unik dari wilayah ini adalah seni tari sanghyang penyalin yang diwariskan secara turun temurun dari keluarga dengan keluarga penari. Tarian ini sejatinya merupakan tarian pengembangan dari tari yang berasal dari dari daerah Bug-Bug Karangasem. Tarian ini menggunakan alat khusus berupa tongkat rotan sepanjang 2-5 Meter dalam pementasannya. Image TWA Danau Buyan -Danau Tamblingan sebagai lokasi suci bagi umat hindu, sekaligus wisata alam sangat kuat bagi masyarakat kabupaten sekitarnya. Pada dasarnya ekowisata yang ada di TWA Danau Buyan-Danau Tamblingan sudah ada dan dalam proses berkembang pelan namun, karena berbagai keterbatasan dan isu sosial maka perkembangannya menjadi kurang optimal. Ada beberapa isu sosial dalam pengembangan pada kawasan ini antara lain sebagai berikut :

- Kurangnya kepedulian pengunjung dalam menjaga kebersihan dan fasilitas pengelolaan sampah.

- Minimnya fasilitas pendukung kepariwisataan seperti pusat informasi, fasilitas akomodasi, dan pusat cinderamata yang belum ada.

- Belum adanya diversifikasi atraksi kawasan TWA Danau Buyan Tamblingan.

- Adanya isu persaingan usaha antara pihak pengelola dan masyarakat sekitar. Sebagai contoh apabila pihak pengelola akan menambah fasilitas spot foto maka dikhawatirkan akan menyaingi kelompok binaan di desa sekitarnya.

\section{Dampak terhadap persepsi masyarakat}

Dari keseluruhan hasil analisis persepsi wisatawan terhadap TWA Danau Buyan adalah cukup baik. Persepsi pengunjung didasarkan pada variabel Persepsi Wisatawan Terhadap Fungsi Kawasan, terhadap kebijakan pengelolaan, terhadap aktivitas wisata, terhadap sarana dan prasarana, dan terhadap willingness to pay. Disimpulkan dari 302 responden berpendapat bahwa TWA Danau Buyan selain memiliki fungsi rekreasi juga memiliki fungsi lainnya. Dalam pengelolaan kebijakan sebanyak $40 \%$ wisatawan mengetahui Undang-Undang terkait kehutanan dan menganggap bahwa pembuatan rencana pengelolaan penting sebanyak $37 \%$. Sedangkan atraksi yang menjadi tujuan utama aktivitas wisata adalah kamping sebesar $40 \%$, dengan tujuan utama untuk menikmati danau dan landscape. Persepsi wisatawan terhadap sarana dan prasarana dasar cukup kecuali untuk tempat sampah dan tempat ibadah. Kesediaan wisatawan untuk membayar atau willingness to pay sebesar $86 \%$ dengan jumlah kisaran harga Rp.5000-Rp.10.000. Menurut Purnama Hefi (2018), persepsi yang benar terhadap suatu obyek diperlukan, sebab persepsi merupakan dasar pembentukan sikap dan perilaku pengunjung. Persepsi individu terhadap lingkungannya merupakan faktor penting karena akan berlanjut dalam menentukan tindakan pengunjung tersebut. Perilaku adalah hasil persepsi dan persepsi yang salah bisa menimbulkan perilaku yang salah. Dengan mengetahui persepsi wisatawan/pengunjung pengelola dapat mengukur seberapa dalam tingkat pemahaman dan sejauh mana mereka memahami fungsi, status dan potensi yang bisa dikembangkan dalam kawasan tersebut, dan pada akhirnya semua informasi dapat dijadikan masukan yang baik bagi upaya pengelolaan lingkungan di kawasan tersebut.

\section{SIMPULAN DAN SARAN}

\subsection{Simpulan}

Berdasarkan hasil penelitian yang telah dikemukakan, maka dapat ditarik kesimpulan sebagai berikut:

a. Pada dasarnya kegiatan ekowisata di TWA Danau Buyan sudah ada dan mulai berkembang antara lain telah tersedianya kegiatan berkemah, 
bersepeda, lintas alam, berperahu, dan spot selfie (berdasarkan perjanjian kerjasama antara pengelola dengan pemerintah desa). Disamping potensi keindahan alam tersebut, potensi wisata budaya dan spiritual seperti tarian sang hyang penyalin dan keberadaan Pura Ulun Danu juga sampai saat perlu dikembangkan. Salah satu sebab kegiatan ekowisata di TWA Danau Buyan mulai berkembang adalah karena organisasi-organisasi yang ada di desa lebih maju, dan dinamis.

b. Persepsi pengunjung didasarkan pada variabel Persepsi Wisatawan Terhadap Fungsi Kawasan, terhadap kebijakan pengelolaan, terhadap aktivitas wisata, terhadap sarana dan prasarana, dan terhadap willingness to pay pada umumnya cukup baik.

c. Berdasarkan Tabel IE matrik strategi pengelolaan lingkungan di TWA Danau Buyan termasuk dalam kuadaran $\mathrm{V}$ (lima) atau hold and maintain/ menjaga dan bertahan, dengan skor bobot 2,88;2,71.

\subsection{Saran}

Berdasarkan hasil penelitian di atas maka penulis mencoba menyampaikan saran terkait dengan persepsi pengunjung terhadap daya tarik TWA Danau Buyan- Danau Tamblingan di Kecamatan Sukasada Kabupaten Buleleng.

a. Untuk pihak pengelola TWA Danau Buyan -Danau Tamblingan di Kabupaten Buleleng kedepan diusulkan dapat memperbaiki fasilitas sarana dan prasarana wisata dan membuat jadwal pemeliharaan fasilitas tersebut. Hal ini ditujukan agar TWA Danau Buyan tetap diminati oleh wisatawan dari dalam dan luar pulau Bali. Selain itu pengembangan kerjasama pengelolaan obyek wisata dengan masyarakat setempat dapat lebih ditingkatkan.

b. Sebaiknya pihak pengelola membangun pusat informasi dan pusat cenderamata pada kawasan ini, disamping juga pihak pengelola giat melakukan promosi TWA Danau Buyan -Danau Tamblingan lewat media cetak atau elektronik.

c. Untuk pihak akademisi diharapkan penelitian ini dapat menjadi acuan bagi penelitian di lokasi yang sama selanjutnya.

d. Untuk peneliti lain diharapkan lebih memperluas kajian tentang kualitas ekosistem dan daya dukung TWA Danau Buyan terhadap pengunjung.

\section{DAFTAR PUSTAKA}

Anonim, 2019.Rencana Pengelolaan Danau Buyan dan Tamblingan, Balai Pengelolaan Daerah Aliran Sungai dan Hutan Lindung Unda anyar. Kementerian Lingkungan Hidup dan Kehutanan.

Alfatinda, Chania, 2017. Dampak Ekowisata (Eko-Agrowisata) Terhadap Sosial Ekonomi Masyarakat di Desa Cibuntu (Studi Kasus di Desa Cibuntu, Kecamatan Pasawahan, Kabupaten Kuningan, Jawa Barat) (Skripsi). Bandung : Universitas Padjajaran.

Balai Konservasi Sumber Daya Alam Bali, 2016. TWA Danau Buyan dan Danau Tamblingan. Available from URL:http://.ksda-bali.go.id (dikutip 23 Desember 2018).

Budayasa, I, K, 2016. Pengembangan Wisata Trekking di Kawasan Danau Buyan, Desa Pancasari, Kabupaten Buleleng, JUMPA 2 (2):143-154.

Blumstein, dkk 2017. Ecotourism'S Promise and Peril, A Biological Evaluation. Springer Internasional Publishing, Switzerland.

David, dkk, 2017. Strategic Management. A competitive Advantage Approach, Concepts and Cases, Pearson Education Limited, Edinburg, England.

Dinas Pariwisata Provinsi Bali. 2016. Perencanaan Kawasan strategis Pariwisata Nasional (KSPN).

Forum Danau Indonesia, 2004. Visi Danau Dunia. Terjemahan dari : World Lake Vision. Jakarta : Deputi Bidang 
Pelestarian Lingkungan, Kementerian Lingkungan Hidup. Available from URL : http://ilec.or.jp (dikutip 23 Desember 2018).

Idrus, M 2007. Metode Penelitian Ilmu-ilmu Sosial (Pendekatan Kualitatif dan Kuantitatif), Yogyakarta : UII Press.

Nazir, M 2003. Metodologi Penelitian. Jakarta : Gndisa Indonesia.

Nugroho, Eko 2018. Prinsip-Prinsip Menyusun Kuesioner, Malang : UB.Press

Rangkuti, F 1997. Analisis SWOT, Teknik Membedah Kasus Bisnis, Reorientasi Konsep Perencanaan Strategis untuk Menghadapi Abad 21, Jakarta: Gramedia Pustaka Ilmu.

Rangkuti, F, 2005, Analisis SWOT : Teknik Membedah Kasus Bisnis. Jakarta : Gramedia Pusaka Utama. Jakarta.
Sari, Purnama, Hefy, dkk, 2018. Analisis Persepsi Pengunjung Untuk Pengembangan Hutan Kota Metro Sebagai Obyek Wisata Alam, Gorontalo Jurnal of Forestry Research (1) 2.

Singarimbun M, Effendi S, 1995. Metode Penelitian Survei, Jakarta : LP3ES.

Suastika, K 2019. Design Tapak KPTDH Bali Utara, Dinas Pariwisata Provinsi Bali.

Suhana, Tomo, 2018. Ecology of Bedugul Basin in Bali (A compilation of Ecologies Studies Conducted in Bedugul by Bali Botanical Garden Researcher). Bali :LIPI.

Sugiyono, 2011. Metode Penelitian Kuantitatif, Kualitatif dan $R \& D$. Jakarta : Alfabeta.

Wijayanti hasna, 2019. Panduan Analisis SWOT, Untuk Kesuksesan Bisnis, Quadrant, Yogyakarta. 